\title{
Hubungan Kadar Vitamin D dan Cathelicidin Plasma dengan Kejadian Infeksi Tuberkulosis pada Anak dengan Kontak BTA Positif
}

\author{
Lola Lusita, Finny Fitri Yani, Netti Suharti \\ Departemen Ilmu Kesehatan Anak Fakultas Kedokteran Universitas Andalas/Rumah Sakit M. Djamil, Padang
}

\begin{abstract}
Latar belakang. Vitamin D dan cathelicidin berperan penting dalam sistem imun alamiah terhadap kuman tuberkulosis. Vitamin D memediasi sintesis cathelicidin, melalui ekspresi vitamin D nuclear reseptor (VDR) sehingga cathelicidin dapat membunuh kuman mycobacterium tuberculosis.

Tujuan. Melihat hubungan kadar vitamin D dan cathelicidin dengan kejadian infeksi tuberkulosis pada anak yang kontak dengan penderita tuberkulosis dewasa BTA positif.

Metode. Penelitian cross sectional dengan sampel dibedakan antara terinfeksi tuberkulosis dengan yang tidak terinfeksi tuberkulosis. Sampel dilakukan pengukuran kadar vitamin D, yaitu kadar $25(\mathrm{OH}) \mathrm{D}$ dan cathelicidin plasma. Analisis statistik dengan menggunakan chi square, T-test, Mann-Whitney U, dan uji korelasi Spearman's.

Hasil. Anak terinfeksi tuberkulosis dengan gizi kurang 58\%. Sumber kontak dengan BTA positif tiga anak yang terinfeksi tuberkulosis 54\%. Tidak terdapat defisiensi vitamin D. Rerata kadar vitamin D anak terinfeksi dan tidak terinfeksi tuberkulosis berturut-turut $24,93 \pm 7,42 \mathrm{dan} 24,66 \pm 6,23 \mathrm{ng} / \mathrm{mL}$ ( $\mathrm{p}=0,868$ ). Kadar cathelicidin rendah terdapat pada $62,5 \%$ anak yang terinfeksi tuberkulosis. Pada anak yang terinfeksi dan tidak terinfeksi tuberkulosis berturut-turut 149,76 $\pm 160,76$ dan 190,74 $\pm 184,95 \mathrm{ng} /$ $\mathrm{mL}(\mathrm{p}=0,139)$. Tidak terdapat hubungan kadar vitamin $\mathrm{D}$ dan cathelicidin plasma pada anak dengan kontak BTA positif ( $\mathrm{p}=0,135$ dan $\mathrm{r}=-0,183)$

Kesimpulan. Kadar cathelicidin pada anak yang tidak terinfeksi tuberkulosis cenderung lebih tinggi dibandingkan anak yang tidak terinfeksi, walaupun secara statistik tidak terdapat perbedaan yang bermakna. Sari Pediatri 2015;17(3):200-4.
\end{abstract}

Kata kunci: cathelicidin, vitamin D, kejadian infeksi tuberkulosis

\section{Correlation Between Vitamin D Levels and Cathelicidin Plasma with Incidence of Tuberculosis Infection on Children in Close Contact with Adult Smear-Positive Tuberculosis Patients}

\author{
Lola Lusita, Finny Fitri Yani, Netti Suharti
}

Background. Vitamin D and cathelicidin have an important effect in innate immunity to mycobacterium tuberculosis. Vitamin $\mathrm{D}$ mediates synthesis of cathelicidin, through the expression of the nuclear vitamin D receptor (VDR), so that cathelicidin may kill the mycobacterium tuberculosis.

Objective. To examine correlation of vitamin D and cathelicidin with incidence of tuberculosis infection on children in close contact with adult smear-positive tuberculosis patients.

Method. This study was cross sectional study on children in close contact with adult smear-positive tuberculosis patient and sample are divided into tuberculosis infected and not infected. In the sample measured of level of $25(\mathrm{OH}) \mathrm{D}$ and cathelicidin plasma. Statistic anlysis was performed using chi-square test, T-test, Man Whitney U test, and Spearman's correlation test.

Result. Tuberculosis-infected children suffered from malnutrition as much as $58 \%$. Sources contact with positive three smearpositive were $54 \%$. There is no deficiency of $25(\mathrm{OH}) \mathrm{D}$ in subject. The mean levels of $25(\mathrm{OH}) \mathrm{D}$ on children infected and not infected with mycobacterium tuberculosis was $24.93 \pm 7.42 \mathrm{ng} / \mathrm{ml}$ and $24.66 \pm 6,23 \mathrm{ng} / \mathrm{ml}$, respectivelly. Low levels of cathelicidin present in $62.5 \%$ of children are infected with tuberculosis. The mean levels of cathelidin on children infected and not infected with Mycobacterium tuberculosis was $149.76 \pm 160.76$ and $190.74 \pm 184.95 \mathrm{ng} / \mathrm{ml}$, respectively.

Conclusion. in this study mean cathelicidin levels tends to be high in the not infected children than infected children, although there were no significant statistically differences. Sari Pediatri 2015;17(3):200-4.

Keywords: cathelicidin, $25(\mathrm{OH}) \mathrm{D}$, the incidence of tuberculosis infection

Alamat korespondensi: Dr. Finny Fitry Yani, Sp.A(K), Dr. Lola Lusita. Bagian Ilmu Kesehatan Anak RSUP Dr.M.Djamil, Fakultas Kedokteran Universitas Andalas, Padang. Jl. Perintis Kemerdekaan, Padang. E-mail: finny_fy@idai.or.id, finny_fy@yahoo.com 


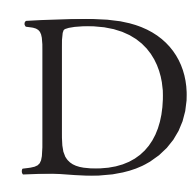
i seluruh dunia, tuberkulosis (TB) masih menjadi masalah utama kesehatan global yang merupakan penyebab utama kedua kematian akibat penyakit menular setelah human immunodefisiensi virus (HIV). Kejadian TB pada anak diperkirakan 490.000 (kisaran, 470.000510.000) pada tahun 2011, setara dengan 6\% jumlah total 8,7 juta insiden kasus. ${ }^{1}$

Infeksi kuman M.tb akan mengaktifkan Tolllike receptor memicu vitamin $\mathrm{D}$ melalui $1,25-\mathrm{OH}$ vitamin $\mathrm{D}$ aktif. Interaksi 1,25-OH vitamin $\mathrm{D}$ dengan vitamin D reseptor (VDR) mengaktifkan gen CAMP untuk menghasilkan peptida antimikroba cathelicidin dan membunuh M.tb. ${ }^{2-4}$ Cathelicidin merupakan peptida antimikroba kationik dan memiliki aktivitas sebagai antimikroba spektrum luas dan memiliki efek imunomodulator, yang dihasilkan oleh neutrofil, epithelial sel paru, keratinosit, monosit, sel mast, dan sel $\gamma \delta$ T. ${ }^{5-7}$

Penelitian ini bertujuan untuk mengetahui hubungan kadar vitamin $\mathrm{D}$ dengan kadar cathelicidin plasma dengan kejadian infeksi tuberkulosis pada anak yang kontak dengan penderita TB dewasa BTA positif.

\section{Metode}

Subjek penelitian adalah anak yang kontak dengan penderita tuberkulosis dewasa BTA positif dengan rentang usia 4 bulan sampai 15 tahun dari bulan Maret-Agustus 2014 di 22 Puskesmas kota Padang.
Kriteria eksklusi adalah riwayat pengobatan TB sebelumnya, baru saja menderita infeksi berat (campak, typhoid, HIV), penyakit kronik (penyakit ginjal kronik dan fibrosis kistik), tidak ada scar BCG, keadaan imunokompromais, obesitas.

Desain penelitian adalah cross sectional yang menggambarkan hubungan kadar vitamin D dan cathelicidin plasma pada anak yang kontak dengan penderita tuberkulosis dewasa BTA positif. Analisis statistik yang digunakan adalah analisis deskriptif, chi kuadrat, $t$-test, dan korelasi regresi.

\section{Hasil}

Terdapat 68 orang anak, 34 terinfeksi dan 34 tidak terinfeksi TB dengan karakteristik berdasarkan umur, jenis kelamin, status gizi, BTA sumber kontak, dan kedekatan dengan sumber kontak (Tabel 1).

Pada Tabel 1 kelompok umur antara anak yang terinfeksi TB dan yang tidak terinfeksi TB sama banyak. Tidak terdapat perbedaan jenis kelamin antara kedua kelompok. Status gizi kurang lebih banyak pada kelompok yang terinfeksi TB dan status gizi baik lebih banyak pada kelompok yang tidak terinfeksi TB, tetapi secara statistik tidak terdapat perbedaan pada kedua kelompok ini. BTA sumber kontak dengan kejadian infeksi TB tidak terdapat perbedaan secara statistik.

Kadar vitamin D diklasifikasikan menjadi tiga kelompok, yaitu defisiensi, insufisiensi, dan normal.

Tabel 1. Karakteristik sampel berdasarkan kejadian infeksi tuberkulosis

\begin{tabular}{|c|c|c|c|c|c|}
\hline \multirow{2}{*}{ Karakteristik } & \multicolumn{2}{|c|}{ Infeksi TB } & \multicolumn{2}{|c|}{ Tidak Infeksi TB } & \multirow{2}{*}{$\mathrm{p}^{*}$} \\
\hline & $\mathrm{F}$ & $\%$ & $\mathrm{~F}$ & $\%$ & \\
\hline \multicolumn{6}{|l|}{ Umur (bulan) } \\
\hline $1--<5$ tahun & 14 & 50 & 14 & 50 & \multirow[t]{3}{*}{1} \\
\hline $5-<10$ tahun & 14 & 50 & 14 & 50 & \\
\hline 10-15 tahun & 6 & 50 & 6 & 50 & \\
\hline \multicolumn{6}{|l|}{ Jenis kelamin } \\
\hline Laki-laki & 19 & 56 & 15 & 44 & \multirow[t]{2}{*}{0,467} \\
\hline Perempuan & 15 & 44 & 19 & 56 & \\
\hline \multicolumn{6}{|l|}{ Status gizi } \\
\hline Kurang & 11 & 55 & 9 & 45 & \multirow{2}{*}{0,595} \\
\hline Baik & 23 & 48 & 25 & 52 & \\
\hline \multicolumn{6}{|c|}{ BTA sumber kontak } \\
\hline+ & 6 & 50 & 6 & 50 & \multirow{3}{*}{0,378} \\
\hline++ & 3 & 30 & 7 & 70 & \\
\hline+++ & 25 & 54 & 21 & 46 & \\
\hline
\end{tabular}

*Uji kai kuadrat 
Kadar cathelicidin juga dikelompokkan menjadi tiga kelompok, yaitu rendah, normal dan tinggi tertera pada Tabel 2.

Pada Tabel 2 tidak ditemukan anak yang mengalami defisiensi vitamin $\mathrm{D}$, tidak terdapat perbedaan klasifikasi kadar vitamin D dengan kejadian infeksi tuberkulosis. Klasifikasi kadar cathelicidin yang rendah lebih banyak pada kelompok terinfeksi TB dibandingkan dengan kelompok yang tidak terinfeksi $\mathrm{TB}$, tetapi tidak terdapat perbedaan secara statistik dengan penderita dewasa BTA positif secara statistik $(\mathrm{p}=0,135)$ dan dengan uji korelasi Spearman's tidak terdapat hubungan $(\mathrm{r}=-0,183)$ antara kadar $25(\mathrm{OH})$ $\mathrm{D}$ dengan kadar cathelicidin serum.

\section{Pembahasan}

Kami mendapatkan 34 anak terinfeksi dan 34 tidak terinfeksi TB. Usia merupakan salah satu faktor risiko

\begin{tabular}{|c|c|c|c|c|c|c|}
\hline \multirow[t]{2}{*}{ Variabel } & & \multicolumn{2}{|c|}{ Infeksi TB } & \multicolumn{2}{|c|}{ Tidak infeksi TB } & \multirow[b]{2}{*}{$\mathrm{p}^{*}$} \\
\hline & & $\mathrm{F}$ & $\%$ & $\mathrm{~F}$ & $\%$ & \\
\hline \multicolumn{7}{|l|}{ Status vitamin $\mathrm{D}(\mathrm{ng} / \mathrm{mL})$} \\
\hline Defisiensi & $(<10)$ & 0 & 0 & 0 & 0 & 0,575 \\
\hline Insufisiensi & $(10--<30)$ & 24 & 47 & 27 & 53 & \\
\hline Normal & $(30-100)$ & 10 & 59 & 7 & 41 & \\
\hline \multicolumn{7}{|c|}{ Status cathelicidin $(\mathrm{ng} / \mathrm{mL})$} \\
\hline Rendah & $(<25)$ & 5 & 62,5 & 3 & 37,5 & 0,681 \\
\hline Normal & $(25-250)$ & 20 & 46,5 & 23 & 53,5 & \\
\hline Tinggi & $(>250)$ & 9 & 53 & 8 & 47 & \\
\hline
\end{tabular}

*Uji kai kuadrat

Tabel 3. Rerata kadar 25(OH)D dan cathelicidin plasma

\begin{tabular}{lccc}
\hline \multirow{2}{*}{ Kadar } & Infeksi & Tidak infeksi & \multirow{2}{*}{$\mathrm{p}$} \\
\cline { 2 - 3 } & Rerata \pm SD & Rerata $\pm S D$ & \multirow{2}{*}{$0,868^{*}$} \\
Vitamin D $(\mathrm{ng} / \mathrm{mL})$ & $24,93 \pm 7,42$ & $24,66 \pm 6,23$ & \\
Cathelicidin $(\mathrm{ng} / \mathrm{mL})$ & $149,76 \pm 160,76$ & $190,74 \pm 184,95$ & $0,139^{* *}$ \\
\hline
\end{tabular}

${ }^{*}$ Uji T Independent

** Uji Mann-Whitney U

Rata-rata kadar vitamin D dan Cathelicidin pada kelompok sampel yang terinfeksi TB dan yang tidak terinfeksi TB tertera pada Tabel 3.

Rerata kadar vitamin D hampir sama antara kedua kelompok dan tidak terdapat perbedaan secara statistik. Rerata kadar cathelicidin lebih tinggi pada kelompok yang tidak terinfeksi TB 190,74 ng/ml (SD 184,95) dibandingkan dengan kelompok terinfeksi TB $149 \mathrm{ng} / \mathrm{ml}$ (SD 160,76), tetapi secara statistik tidak bermakna.

Hubungan kadar $25(\mathrm{OH}) \mathrm{D}$ dan cathelicidin pada anak yang kontak dengan penderita tuberkulosis dewasa BTA positif tertera pada Gambar 1. Pada Gambar 1 tidak terdapat hubungan kadar 25(OH) $\mathrm{D}$ dengan cathelicidin plasma pada anak yang kontak

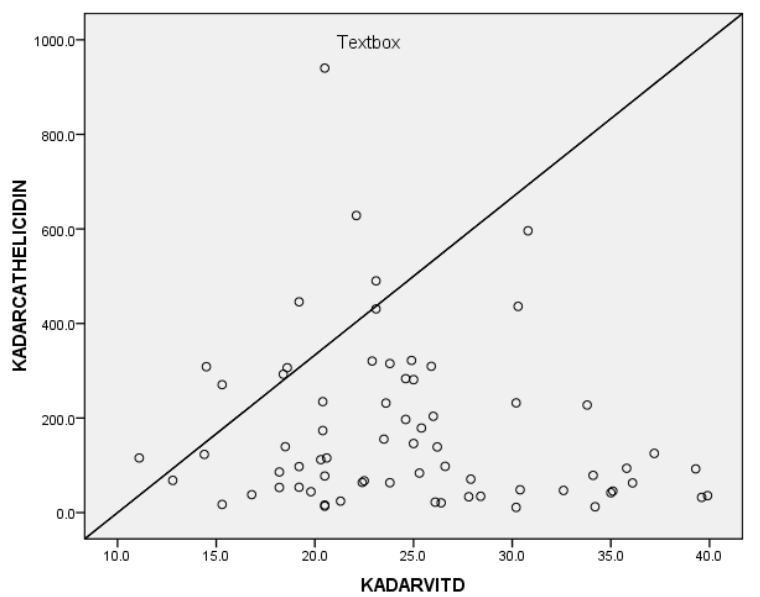

Gambar 1. Korelasi kadar vitamin D dan cathelicidin 
terinfeksi TB, bayi dan anak usia kurang dari 5 tahun lebih berisko terinfeksi TB karena sistem imunitas yang belum berkembang sempurna. ${ }^{8}$ Kami tidak mendapatkan perbedaan umur antara anak terinfeksi dengan tidak terinfeksi TB. Jenis kelamin tidak memengaruhi kejadian infeksi TB. Pada penelitian kami, jenis kelamin secara statistik tidak bermakna. Torne dkk $^{9}$ dan Ruselly ${ }^{10}$ juga melaporkan bahwa tidak terdapat perbedaan secara statistik antara laki-laki dan perempuan.

Status gizi sangat penting dalam penularan terhadap tuberkulosis. Anak dengan status gizi kurang lebih mudah terinfeksi kuman tuberkulosis dibandingkan anak dengan status gizi baik. Kami tidak mendapatkan perbedaan status gizi antara anak terinfeksi dengan yang tidak terinfeksi TB. Laporan penelitian Ruselly ${ }^{10}$ juga mendapatkan hasil yang serupa. Singh $\mathrm{dkk}^{11}$ melaporkan 57,3\% anak yang terifeksi TB dengan malnutrisi berat dan malnutrisi berat memiliki OR 3,97 untuk terjadinya infeksi tuberkulosis.

Sumber infeksi TB pada anak yang terpenting adalah pajanan terhadap orang dewasa yang infeksius, terutama yang memiliki bakteri tahan asam (BTA) positif. Pasien yang memiliki BTA +3 lebih besar menularkan kuman TB. Pada penelitian kami tidak didapatkan perbedaan BTA sumber kontak antara anak terinfeksi dengan tidak terinfeksi tuberkulosis. Hal tersebut mungkin disebabkan karena penelitian kami hanya membandingkan jumlah BTA sputum dengan kejadian infeksi TB. Sementara risiko transmisi kuman dari orang dewasa ke anak bisa seperti infiltrat yang luas atau kavitas pada lobus atas, produksi sputum banyak dan encer, batuk produktif dan kuat, serta terdapat faktor lingkungan yang kurang sehat terutama sirkulasi udara yang tidak baik tidak dimasukkan ke dalam penelitian ini. Laporan penelitian Tornee $\mathrm{dkk}^{9} \mathrm{di}$ Bangkok, 77,32\% anak yang kontak dengan penderita BTA +3 terinfeksi tuberkulosis. Perbedaan tersebut disebabkan karena penelitian Tornee menggunakan sampel yang lebih besar, meneliti 500 anak yang kontak dengan penderita dewasa BTA positif.

Klasifikasi kadar vitamin D dan rata-rata vitamin D dengan kejadian infeksi TB pada anak yang kontak dengan penderita TB dewasa BTA positif tidak berbeda secara statistik antara anak yang terinfeksi dengan anak yang tidak terinfeksi TB. Kami hanya meneliti kadar vitamin $\mathrm{D}$, sedangkan faktor yang memengaruhi kadar vitamin $\mathrm{D}$, seperti lama paparan sinar matahari dan asupan makanan yang mengandung vitamin $\mathrm{D}$, tidak dilakukan. Dengan demikian, hal ini mungkin bisa menjadi salah satu faktor yang menyebabkan tidak terdapat perbedaan antara kadar vitamin $\mathrm{D}$ antara kelompok yang tidak terinfeksi TB dengan kelompok yang terinfeksi TB. Laporan penelitian Yamshichikof $\mathrm{dkk}^{12}$ pada penderita TB dewasa didapatkan $86 \%$ pasien mengalami insufisiensi vitamin D.

Pada penelitian kami, kadar cathelicidin anak yang terinfeksi tuberkulosis lebih rendah daripada yang tidak terinfeksi tuberkulosis. Cathelicidin yang diukur adalah cathelicidin yang terdapat di dalam plasma sehingga kadarnya juga bisa dipengaruhi oleh rangsangan inflamasi dan infeksi lain selain kuman TB. Kadar cathelicidin yang lebih spesifik akibat infeksi M.tb dapat diperiksa di sel epitel saluran nafas dan makrofag alveolar. ${ }^{13}$

Kami tidak mendapatkan hubungan antara kadar vitamin D dengan cathelicidin anak yang kontak dengan penderita dewasa BTA positif. Yamshichikof $\mathrm{dkk}$, meneliti hubungan antara kadar vitamin $\mathrm{D}$ dengan cathelicidin pada pasien TB dewasa, juga tidak mendapatkan hubungan antara kadar vitamin D dan cathelicidin. ${ }^{12,14,15}$ Hal tersebut mungkin disebabkan karena vitamin $\mathrm{D}$ tidak langsung memengaruhi sintesis cathelicidin tetapi melalui 1,25 $(\mathrm{OH}) 2 \mathrm{D}$ dan ekspresi dari VDR.

\section{Kesimpulan}

Rerata kadar cathelicidin anak terinfeksi tuberkulosis lebih rendah dibandingkan anak tidak terinfeksi tuberkulosis yang kontak dengan penderita dewasa BTA positif, tetapi perbedaan ini tidak bermakna secara statistik dan tidak terdapat hubungan antara kadar vitamin $\mathrm{D}$ dengan kadar cathelicidin plasma pada anak yang kontak dengan penderita tuberkulosis dewasa BTA positif.

\section{Daftar pustaka}

1. World Health Organization. Global tuberculosis report 2012.Switzerland:World Health Organization;2012.

2. Liu PT, Stefen S, Li H, Wenzel L, Tan BH, Krutzik SR, dkk. Toll-like receptor triggering of vitamin D-mediated human antimicrobial response. Science 2006;311:1770-3.

3. Adams JS, Liu PT, Chun R, Modlin RL, Hewison M. 
Vitamin D in defense of human immune response. Ann N Y Acad Sci 2007;1117:94-105.

4. Edfelt K, Liu PT, Chun R, Fabri M, Schenk M, Wheelwright M, dkk. T-cell cytokines differentally control human monocyte antimicrobial responses by regulating vitamin D metabolism. PNAS 2010;107:22593-8.

5. Doss M, White MR, Tecle T, Hartshorn KL. Human defensin and LL-37 in mucosal immunity. J Leukoc Biol 2010;87:79-92.

6. Agerberth B, Charo J, Werr J, Olsson B, Idali F, lindbom L, dkk. The human antimicrobial and chemotactic peptides LL-37 and a-defensins are expressed by specific lymphocyte and monocyte populations. Blood 2000;96:3086-93.

7. Nijnik A, Hanocock REW. The role of cathelicidin LL37 in immune defenced and novel clinical applications. Curr Opin Hematol 2009; 16:41-7.

8. Kartasasmita CB, Basir D. Tuberkulosis. Dalam: Rahayu NN, Supriyatno B, Setyanto DB, penyunting. Buku ajar respirologi anak. Jakarta: Ikatan Dokter Anak Indonesia; 2008.h.162-8.

9. Tornee S, Kaewkungwal J, Fungladda W, Silachamroon U, Akarawesi P, Sunakorn P. Risk factors for tuberculosis infection among household contacs in Bangkok, Thailand. Southeast Asian J Trop Med Pub 2004;33:375-83.

10. Ruselly A. Perbandingan tuberkulin skin tes dengan enzyme linked immunosorbent spot assay tuberkulosis untuk diagnostik infeksi tuberkulosis anak dengan kontak tuberkulosis dewasa BTA positif Padang (Tesis). Universitas Andalas; 2012.

11. Singh M, Mynak ML, Kumar L, Mathew JL, Jindal SK. Prevalence and risk factors for transmission of infection among children in household contact with adults having pulmonary tuberculosis. Arch Dis Child 2006;90:624-8.

12. Yamshchikov AV, Kurbatova EV, Kumari M, Blunberg HM, Ziegler TR, Ray SM, dkk. Vitamin D status and antimicrobial peptide cathelicidin (LL-37) concentrations in patients with active pulmonary tuberculosis. AM J Clin Nutr 2010;92:603-11.

13. Li Y, Wang Y, Liu X. The role of airway epithelial Cells in response to mycobacteria infection. Clin Develop Immunol 2012;1-12.

14. Iacob SA, Panaitescu E, Iacob DG, Cojocaru M. The human cathelicidin LL37 peptide has high plasma levels in B and C hepatitis related to viral activity but not to 25-hydroxyvitamin D plasma level. Rom J Intern Med 2012;5:217-23.

15. Gombart AF, Bhan I, N B. Low plasma level of cathelicidin antimicrobial peptide (hCAP18) predicts increased infectious disease mortality in patients undergoing hemodialysis. CID 2009;48:418-24. 